\title{
MODIFIKASI CAESAR CIPHER DENGAN PERMUTASI, TRANSPOSISI, BINARY, GERBANG LOGIKA, ASCII DAN HEXA
}

\author{
Akhmad Syarif \\ Magister Teknik Informatika Universitas AMIKOM Yogyakarta \\ Jl. Ring Road Utara. Condong Catur, Sleman, Yogyakarta \\ akhmad.syarifestudents.amikom.ac.id
}

\begin{abstract}
Cryptography is the art of securing and keeping text or message from other people except those who receive it. Caesar Cipher algorithm is a classic algorithm that is vulnerable to hacker attacks by the brute force method. Caesar Cipher with 7 methods, the first is a transposition, the second is a permutation, the third is binary converting, the fourth is logistic gate calculation, the sixth is converting ASCII and the seventh is converting Hexa. With seven combinations of these methods, it can improve Caesar's algorithm Cipher from hacker attacks and add variations to the modification of Caesar Cipher in classical encryption. Making ciphertext very complex and to overcome so many possibilities that must be tried.
\end{abstract}

Keywords - Caesar Cipher, Modification, Convert, Transposition.

\begin{abstract}
Abstrak - Kriptografi adalah seni dalam mengamankan dan merahasiakan suatu teks atau pesan dari orang lain kecuali yang menerima. Algoritma Caesar Cipher adalah algoritma klasik yang rentan akan serangan hacker dengan metode brute force. Pada penelitian ini dilakukan memodifikasi algoritma Caesar Cipher dengan 7 metode yaitu pertama adalah tranposisi, ke-dua permutasi, ke-tiga convert biner, ke-empat perhitungan gerbang logika, ke-enam convert ASCII dan ke-tujuh convert hexa. Dengan tujuh kombinasi metode ini harapan bisa memperkuat algoritma Caesar Cipher dari serangan hacker dan menambah variasi modifikasi dari Caesar Cipher dalam enkripsi klasik. Menjadikan ciphertext sangat komplek dan untuk mengatasinya begitu banyak kemungkinan yang harus dicoba.
\end{abstract}

Kata Kunci - Caesar Cipher, Modifikasi, Mengubah, Transposisi.

\section{PENDAHULUAN}

Saat ini pertukaran data dalam bentuk pesan atau teks secara digital melalui jaringan internet secara publik telah banyak dilakukan. Sehingga salah satu permasalahan yang terjadi dari hal tersebut adalah keamanan teks yang dikirimkan ataupun yang diterima[1].

Kriptografi adalah ilmu merancang metode yang memungkinkan informasi dikirim dalam bentuk yang aman sedemikian rupa cara satu-satunya orang yang dapat mengambil informasi ini penerima yang dimaksud [2]. Awalnya kriptografi dulu dilakukan dengan teknik manual. Kerangka dasar melakukan kriptografi tetaplah sama pada dulu hingga banyak dilakukan sampai sekarang ke kriptografi modern. Ada 2 cara dalam menyembunyikan informasi yaitu kriptografi dan steganografi. Kriptografi terdiri dari 2 bagian, yaitu enkripsi dan dekripsi [3]. Enkripsi adalah proses mengubah teks biasa (plaintext) menjadi teks yang acak (chipertext) [3]. Dekripsi adalah mengubah teks acak (ciphertext) menjadi teks biasa (plaintext) [3] Algoritma kriptografi dibagi menjadi 2 bagian yaitu kriptografi klasik dan kriptografi modern. Kriptografi klasik adalah algoritma yang pada umumnya digunakan pada jaman dulu dengan hanya menggunakan metode subtitusi dan permutasi [4]. Sedangkan kriptografi modern adalah algoritma yang digunakan pada jaman sekarang. Hasil dari pengembangan kriptografi klasik dimana didalam prosesnya ditambahkan penggunaan biner, hexa dll.

Caesar Cipher adalah algoritma klasik substitusi terlama bahkan tertua yang terkenal sampai sekarang. Caesar cipher tidak memiliki kunci dalam algoritma enkripsinya dimana keamanan dari algoritma tersebut terletak pada kerahasiaan algoritmanya itu sendiri. Seiring dengan waktu algoritma ini semakin ditinggal oleh zaman sekarang dikarenakan dianggap kurang aman. Oleh karena itu diperlukan untuk memodifikasi dengan beberapa metode dari algoritma klasik lainnya seperti tranposisi dan lainya untuk meningkatkan dan memberikan kekuatan lebih pada hasil enkripsi agar kesulitian dalam teknik brute force [5]. Pada umum nya enkripsi dan dekripsi pada Caesar Cipher adalah [1] :

Enkripsi :

Dekirpsi :

$$
E(x)=x+K \bmod 26
$$

$$
D(x)=x-K \bmod 26
$$

Dimana $\mathrm{K}$ adalah nilai kunci yang digunakan untuk menggeser setiap karakter $\mathrm{x}$.

Misal dengan mengkodekan setiap huruf alfabet dengan sebuah angka integer: $\mathrm{A}=0, \mathrm{~B}=1, \mathrm{C}=2, \mathrm{D}=$ $3, \mathrm{E}=4, \mathrm{~F}=5, \mathrm{G}=6, \mathrm{H}=7, \mathrm{I}=8, \mathrm{~J}=9, \mathrm{~K}=10, \mathrm{~L}=$ $11, \mathrm{M}=12, \mathrm{~N}=13, \mathrm{O}=14, \mathrm{P}=15, \mathrm{Q}=16, \mathrm{R}=17, \mathrm{~S}$ $=18, \mathrm{~T}=19, \mathrm{U}=20, \mathrm{~V}=21, \mathrm{~W}=22, \mathrm{X}=23, \mathrm{Y}=24$, $\mathrm{Z}=25$. Pergesaran 2 huruf alfabet di dalam Caesar Cipher dengan melakukan penjumlahan plainteks 
(p) dengan 2 dalam modulus 26 atau dalam bentuk kesamaan [6]:

$$
E(p)=p+2 \bmod 26
$$

Untuk melakukan dekripsi dengan operasi kebalikan dari enkripsi, dengan pengurangan cipherteks (c) dengan 3 dalam modulus 26 :

$$
E(c)=c-2 \bmod 26
$$

Dimana :

$p=$ plaintext

$c=$ chipertext

Algoritma Caesar Cipher adalah algoritma yang melakukan pergantian posisi huruf awal dengan alphabet atau disebut dengan ROT3. Algoritma transposisi adalah dengan cara mengubah letak dari teks pesan yang disandikangn dengan menggunakan pola tertentu [7].

Algoritma SPICA-XB adalah algoritma yang menggabungkan sifat algoritma kriptografi Caesar Cipher dengan beberapa sifat dari algoritma kriptografi modern [8].

Priya Verma dan teman-teman dengan judul Modified Caesar Cipher using Rectangular Method For Enhanced Security. Mereka melakukan modifikasi kriptografi Caesar Cipher dengan metode rectangular. Mereka memberikan nama kepada teknik yang mereka rancang dengan nama MCC. Teknik MCC menggunakan subtitusi dan tranposisi pada teks biasa dan menggunakan 2 kunci berbeda untuk enkripsi sehingga membuat lebih kuat dan aman.

Galih Fathul Rohmi dan teman-teman dengan judul Implementasi Algoritma Cipher Ceasar untuk Enkripsi dan Dekripsi pada Tabel ASCII menggunakan Bahasa Java. Mereka melakukan modifikasi pada kriptografi dengan menambahkan tabel ASCII untuk memperkuat hasil enkripsi dengan menggunakan bahasa JAVA.

Fahrul Ikhsan Lubis dan teman-teman dengan judul Combination of Caesar Cipher Modification with Transposition Cipher. Mereka melakukan modifikasi pada kriptografi Caesar Cipher dengan penambahan transposisi sehingga terdapat $3 x$ proses enkripsi yang mengharuskan cryptanalis harus menemukan algoritma yang digunakan, karakter yang ditambahkan, bagian yang tidak terenkripsi dan mencari kunci yang digunakan.

Penelitian ini betujuan untuk memperkuat kriptografi pada Ceasar Cipher dengan beberapa tambahan metode dari algoritma klasik lainnya sehingga kriptografi Caesar Cipher menjadi lebih kuat dan lebih sulit untuk dipecah dari pada kriptografi Caesar Cipher klasik. Yang membedakan dari penelitian terdahulu diatas adalah metode yang digunakan peneliti menggunakan 7 metode algoritma dengan permutasi, tranposisi, binary, perhitungan gerbang logika dan juga vonversi ke ASCII dan hexa. Salah satu metode yang sering digunakan yaitu perubahan ASCII ke dalam biner untuk enkripsi dan sebaliknya untuk dekripsi [9]. Sehingga mempersulit bagi cryptanalis dalam memecahkan kriptografi ini.

\section{METODE PENELITIAN}

Dalam perkembangan ilmu kriptografi semakin luas dan banyak sekali dimanfaatkan terutama dalam mengamankan informasi.

Pada kasus ini untuk algoritma klasik Cipher Caesar sendiri diterapkan pada aspek transposisi huruf dengan huruf yang diacak. Dilanjutkan dengan conversi ke biner lalu subtitusi gerbang logika yang dilakukan 4 kali dan dilanjutkan substitusi tabel ASCII dan Hexa pada huruf tertentu.

Langkah enkripsi pada implementasi di program ini adalah memasukan plaintext dan kunci sesuai keinginan dengan banyak kunci 2. Misal kunci HALO dan kunci GUNUNG MERAPI. Pertama hapus huruf yang terlihat double sehingga terlihat hanya ada 1 huruf saja dalam deretan tersebut. Dalam kunci HALO akan tetap menjadi HALO karena dari deretan tersebut tidak terdapat huruf double atau perulangan huruf sehingga tidak ada perubahaan. Jika pada kunci GUNUNG MERAPI terdapat beberapa huruf double yaitu U, N, G sehingga menjadi GUNMERAPI, disini juga akan dihapus spasi yang ada sehingga menjadi 1 kata saja.

Lalu dilakukan tranposisi huruf pada kunci dengan table 1 dibawah ini, dengan memasukan huruf pada kunci diawal box, dan dilanjutkan huruf alpabet dari $\mathrm{Z}$ sampai A dimana huruf tidak boleh ada yang double.

Tabel 1. Tabel Transposisi 1 kunci HALO

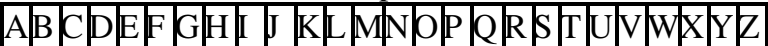

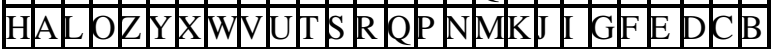

Pada kunci ke 2 juga sama seperti transposisi kunci ke 1 . Bisa dilihat pada table 2 dibawah ini :

Tabel 2. Tabel Transposisi 1 kunci GUNUNG MERAPI

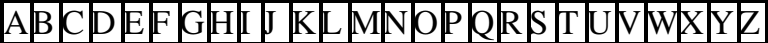
GUNMER A P I Z

Dilanjutkan dengan mengubah kalimat plaintext menjadi satu kata yaitu mengganti space dengan tanda simbol underscore ( _ $)$. Dengan plaintext adalah SAYA MAU MAKAN KETEMPAT YANG JAUH DARI KOTA. Menjadi SAYA_MAU_MAKAN_KETEMPAT_YANG_JAU H_DARI_KOTA.

Lalu dilanjutkan tranposisi plaintext dengan table tranposisi kunci yang telah dibuat sebelumnya. Dengan urutan huruf 1 dari plaintext ditransposisi dengan hasil transposisi kunci 1 , urutan huruf 2 dari plaintext ditransposisi dengan hasil transposisi kunci 2, urutan huruf 3 dari plaintext ditransposisi dengan hasil transposisi 1 dan diulang terus urutannya dari kunci 1 , kunci 2 dan balik lagi ke kunci 1 sampai huruf terakhir plaintext. Trnaposisi pada plaintext bisa dilihat pada tabel 3 dibawah ini : 
Tabel 3. Tabel Transposisi plaintext

\begin{tabular}{|l|l|l|l|l|l|l|l|l|l|l|l|l|l|l|l|l|}
\hline $\mathrm{K}$ & $\mathrm{K}$ & $\mathrm{K}$ & $\mathrm{K}$ & $\mathrm{K}$ & $\mathrm{K}$ & $\mathrm{K}$ & $\mathrm{K}$ & $\mathrm{K}$ & $\mathrm{K}$ & $\mathrm{K}$ & $\mathrm{K}$ & $\mathrm{K}$ & $\mathrm{K}$ & $\mathrm{K}$ & $\mathrm{K}$ & $\mathrm{K}$ \\
1 & 2 & 1 & 2 & 1 & 2 & 1 & 2 & 1 & 2 & 1 & 2 & 1 & 2 & 1 & 2 & 1 \\
\hline $\mathrm{K}$ & $\mathrm{E}$ & $\mathrm{T}$ & $\mathrm{I}$ & $\mathrm{K}$ & $\mathrm{A}$ & $\mathrm{C}$ & $\mathrm{O}$ & $\mathrm{R}$ & $\mathrm{O}$ & $\mathrm{N}$ & $\mathrm{A}$ & $\mathrm{D}$ & $\mathrm{A}$ & $\mathrm{T}$ & $\mathrm{A}$ & $\mathrm{N}$ \\
\hline $\mathrm{T}$ & $\mathrm{E}$ & $\mathrm{G}$ & $\mathrm{I}$ & $\mathrm{T}$ & $\mathrm{G}$ & $\mathrm{L}$ & $\mathrm{T}$ & $\mathrm{J}$ & $\mathrm{T}$ & $\mathrm{Q}$ & $\mathrm{G}$ & $\mathrm{O}$ & $\mathrm{G}$ & $\mathrm{G}$ & $\mathrm{G}$ & $\mathrm{Q}$ \\
\hline
\end{tabular}

Tabel 4. Tabel LanjutanTransposisi plaintext

\begin{tabular}{|l|l|l|l|l|l|l|l|l|l|l|l|l|l|l|l|l|}
\hline $\mathrm{K}$ & $\mathrm{K}$ & $\mathrm{K}$ & $\mathrm{K}$ & $\mathrm{K}$ & $\mathrm{K}$ & $\mathrm{K}$ & $\mathrm{K}$ & $\mathrm{K}$ & $\mathrm{K}$ & $\mathrm{K}$ & $\mathrm{K}$ & $\mathrm{K}$ & $\mathrm{K}$ & $\mathrm{K}$ & $\mathrm{K}$ & $\mathrm{K}$ \\
2 & 1 & 2 & 1 & 2 & 1 & 2 & 1 & 2 & 1 & 2 & 1 & 2 & 1 & 2 & 1 & 2 \\
\hline $\mathrm{G}$ & $\mathrm{E}$ & $\mathrm{N}$ & $\mathrm{G}$ & $\mathrm{K}$ & $\mathrm{A}$ & $\mathrm{U}$ & $\mathrm{D}$ & $\mathrm{I}$ & $\mathrm{P}$ & $\mathrm{A}$ & $\mathrm{K}$ & $\mathrm{S}$ & $\mathrm{A}$ & $\mathrm{M}$ & $\mathrm{E}$ & $\mathrm{N}$ \\
\hline $\mathrm{A}$ & $\mathrm{Z}$ & $\mathrm{V}$ & $\mathrm{X}$ & $\mathrm{Y}$ & $\mathrm{H}$ & $\mathrm{J}$ & $\mathrm{O}$ & $\mathrm{I}$ & $\mathrm{M}$ & $\mathrm{G}$ & $\mathrm{T}$ & $\mathrm{L}$ & $\mathrm{H}$ & $\mathrm{W}$ & $\mathrm{Z}$ & $\mathrm{V}$ \\
\hline
\end{tabular}

Tabel 5. Tabel Lanjutan Transposisi plaintext

\begin{tabular}{|l|l|l|l|l|l|l|l|l|}
\hline K1 & K2 & K1 & K2 & K1 & K2 & K1 & K2 & K1 \\
\hline C & A & R & I & T & U & H & A & N \\
\hline L & G & $\mathrm{J}$ & $\mathrm{I}$ & $\mathrm{G}$ & $\mathrm{J}$ & $\mathrm{W}$ & $\mathrm{G}$ & $\mathrm{Q}$ \\
\hline
\end{tabular}

Maka

akan menjadi IGBG_RGF_WHYHV_TEGERSHK_BGQA_UGFP_ OGJI_TTGG.

Selanjutnya hasil dari transposisi plaintext tadi didapatkan hasil ciphertext pertama yang akan dilanjutkan dengan permutasi, yang mana huruf urutan genap pada hasil ciphertext pertama akan di mutasi ke angka sesuai tabel 4 dibawah ini.

Tabel 6. Tabel Mutasi Hasil Ciphertext 1

A BCDEFF G H I J $\begin{array}{lllllllllllllllllllllllllll}1 & 2 & 3 & 4 & 5 & 6 & 7 & 8 & 9 & 1 & 1 & 1 & 1 & 1 & 1 & 1 & 1 & 1 & 1 & 2 & 2 & 2 & 2 & 2 & 2 & 2\end{array}$

Maka hasilnya adalah I7B7_18G6_23H25H22_20E7E18S8K_B7Q1_21G6P _O7J9_20T7G.

Lalu dilanjutkan dengan conversi kunci 1, kunci 2 dan hasil mutasi ciphertext 1 kedalam bentuk biner. Untuk conversi ASCII ke Biner bisa dilihat pada gambar 1 dibawah ini.

\begin{tabular}{|c|c|c|c|c|c|c|c|c|c|c|c|c|c|c|c|}
\hline Oct & Dec & Hex & Char & Oct & Dec & Hex & Char & Oct & Dec & Hex & Char & Oct & Dec & Hex & Char \\
\hline$\overline{000}$ & 0 & $\bar{\infty}$ & $\overline{\text { NULL }}$ & 040 & 32 & 20 & SPACE & $\overline{100}$ & 64 & 40 & $\overline{2}$ & 140 & 96 & 60 & T \\
\hline$\infty 1$ & 1 & 01 & $\mathrm{SOH}$ & 041 & 33 & 21 & $!$ & 101 & 65 & 41 & A & 141 & 97 & 61 & a \\
\hline 002 & 2 & 02 & STX & 042 & 34 & 22 & $"$ & 102 & 66 & 42 & B & 142 & 98 & 62 & b \\
\hline$\infty 03$ & 3 & 03 & ETX & 043 & 35 & 23 & \# & 103 & 67 & 43 & c & 143 & 99 & 63 & c \\
\hline$\infty 4$ & 4 & 04 & $E O T$ & 044 & 36 & 24 & s & 104 & 68 & 44 & D & 144 & 100 & 64 & $\mathrm{~d}$ \\
\hline 005 & 5 & 05 & ENQ & 045 & 37 & 25 & : & 105 & 69 & 45 & E & 145 & 101 & 65 & e \\
\hline 006 & 6 & 06 & $A C K$ & 046 & 38 & 26 & $\&$ & 106 & 70 & 46 & F & 146 & 102 & 66 & $\mathrm{f}$ \\
\hline$\infty 07$ & 7 & 07 & $B E L$ & 047 & 39 & 27 & ' & 107 & 71 & 47 & G & 147 & 103 & 67 & g \\
\hline 010 & 8 & as & BS & 050 & 40 & 28 & ( & 110 & 72 & 48 & H & 150 & 104 & 68 & $\mathrm{~b}$ \\
\hline 011 & 9 & 09 & $H T$ & 051 & 41 & 29 & ) & 111 & 73 & 49 & I & 151 & 105 & 69 & $i$ \\
\hline 012 & 10 & $\mathrm{OA}$ & $L F$ & 052 & 42 & $2 \mathrm{~A}$ & * & 112 & 74 & $4 \mathrm{~A}$ & $\mathrm{~J}$ & 152 & 106 & $6 \mathrm{~A}$ & $j$ \\
\hline 013 & 11 & $\mathrm{OB}$ & $V T$ & 053 & 43 & $2 B$ & + & 113 & 75 & $4 B$ & $\mathrm{~K}$ & 153 & 107 & $6 \mathrm{~B}$ & $\mathrm{k}$ \\
\hline 014 & 12 & $O C$ & $F F$ & 054 & 44 & $2 C$ & , & 114 & 76 & $4 C$ & L & 154 & 108 & $6 C$ & 1 \\
\hline 015 & 13 & $O D$ & $C R$ & 055 & 45 & $2 \mathrm{D}$ & - & 115 & 77 & $4 \mathrm{D}$ & M & 155 & 109 & $6 \mathrm{D}$ & $\mathrm{m}$ \\
\hline 016 & 14 & $\mathrm{OE}$ & SO & 056 & 46 & $2 \mathrm{E}$ & . & 116 & 78 & $4 \mathrm{E}$ & 11 & 156 & 110 & $6 \mathrm{E}$ & ב ב \\
\hline 017 & 15 & $\mathrm{OF}$ & $S I$ & 057 & 47 & $2 \mathrm{~F}$ & / & 117 & 79 & $4 \mathrm{~F}$ & 0 & 157 & 111 & $6 \mathrm{~F}$ & $\circ$ \\
\hline 020 & 16 & 10 & $D L E$ & 060 & 48 & 30 & 0 & 120 & 80 & 50 & P & 160 & 112 & 70 & $p$ \\
\hline 021 & 17 & 11 & $D C 1$ & 061 & 49 & 31 & 1 & 121 & 81 & 51 & $Q$ & 161 & 113 & 71 & $q$ \\
\hline 022 & 18 & 12 & $D C 2$ & 062 & 50 & 32 & 2 & 122 & 82 & 52 & $\mathrm{R}$ & 162 & 114 & 72 & $r$ \\
\hline 023 & 19 & 13 & $D C 3$ & 063 & 51 & 33 & 3 & 123 & 83 & 53 & $s$ & 163 & 115 & 73 & $s$ \\
\hline 024 & 20 & 14 & $D C 4$ & 064 & 52 & 34 & 4 & 124 & 84 & 54 & $\mathrm{~T}$ & 164 & 116 & 74 & t \\
\hline 025 & 21 & 15 & NAK & 065 & 53 & 35 & 5 & 125 & 85 & 55 & $\mathrm{u}$ & 165 & 117 & 75 & $\mathrm{u}$ \\
\hline 026 & 22 & 16 & $S Y N$ & 066 & 54 & 36 & 6 & 126 & 86 & 56 & $\mathrm{v}$ & 166 & 118 & 76 & $\mathrm{v}$ \\
\hline 027 & 23 & 17 & ETB & 067 & 55 & 37 & 7 & 127 & 87 & 57 & ฑ & 167 & 119 & 77 & $w$ \\
\hline 030 & 24 & 18 & $C A N$ & 070 & 56 & 38 & 8 & 130 & 88 & 58 & $\mathrm{x}$ & 170 & 120 & 78 & $\mathrm{x}$ \\
\hline 031 & 25 & 19 & $E M$ & 071 & 57 & 39 & 9 & 131 & 89 & 59 & $\mathrm{Y}$ & 171 & 121 & 79 & $\mathrm{y}$ \\
\hline 032 & 26 & $1 \mathrm{~A}$ & $S U I B$ & 072 & 58 & $3 \mathrm{~A}$ & : & 132 & 90 & $5 \mathrm{~A}$ & z & 172 & 122 & $7 \mathrm{~A}$ & $z$ \\
\hline 033 & 27 & $1 B$ & ESC & 073 & 59 & 3B & ; & 133 & 91 & $5 B$ & [ & 173 & 123 & $7 \mathrm{~B}$ & 1 \\
\hline 034 & 28 & $1 C$ & FS & 074 & 60 & $3 c$ & $<$ & 134 & 92 & $5 C$ & $\backslash$ & 174 & 124 & $7 C$ & 1 \\
\hline 035 & 29 & $1 D$ & GS & 075 & 61 & 3D & - & 135 & 93 & $5 \mathrm{D}$ & ] & 175 & 125 & $7 \mathrm{D}$ & j \\
\hline 036 & 30 & $1 \mathrm{E}$ & RS & 076 & 62 & $3 \mathrm{E}$ & $>$ & 136 & 94 & $5 \mathrm{E}$ & & 176 & 126 & $7 \mathrm{E}$ & $\sim$ \\
\hline 037 & 31 & $1 \mathrm{~F}$ & US & 077 & 63 & $3 \mathrm{~F}$ & $?$ & 137 & 95 & $5 \mathrm{~F}$ & & 177 & 127 & $7 \mathrm{~F}$ & $D E L$ \\
\hline
\end{tabular}

Gambar 1. Tabel Decimal-Binary-Octal-Hex-ASCII

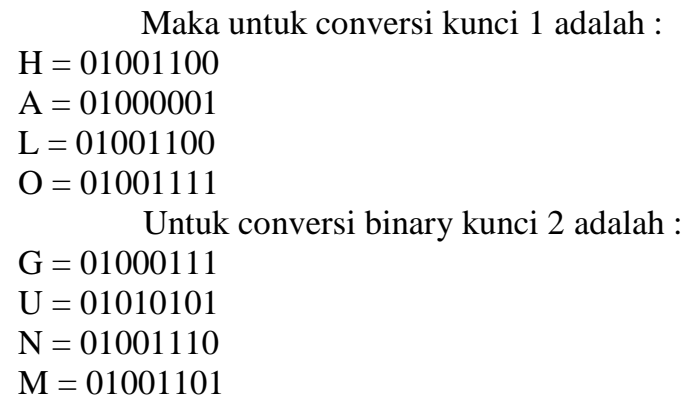

$$
\begin{aligned}
& E=01000101 \\
& R=01010010 \\
& A=01000001 \\
& P=01010000 \\
& I=01001001
\end{aligned}
$$

Dan untuk conversi binary dari plaintext yang telah menjadi chipertext 1 tadi adalah :

$$
\begin{aligned}
& \mathrm{I}=01001001 \\
& 7=00000111 \\
& \mathrm{~B}=01000010
\end{aligned}
$$




$$
\begin{aligned}
& 7=00000111 \\
& -=01011111 \\
& \overline{18}=00010010 \\
& \mathrm{G}=01000111 \\
& 6=00000110 \\
& =01011111 \\
& \overline{2} 3=00010111 \\
& \mathrm{H}=01001000 \\
& 25=00011001 \\
& \mathrm{H}=01001000 \\
& 22=00010110 \\
& =01011111 \\
& \overline{20}=00010100 \\
& \mathrm{E}=01000101 \\
& 7=00000111 \\
& \mathrm{E}=01000101 \\
& 18=00010010 \\
& \mathrm{~S}=01010011 \\
& 8=00001000 \\
& \mathrm{~K}=01001011 \\
& -=00000000 \\
& \overline{\mathrm{B}}=01000010 \\
& 7=00000111 \\
& \mathrm{Q}=01010001 \\
& 1=00000001 \\
& =01011111 \\
& \overline{2} 1=00010101 \\
& \mathrm{G}=01000111 \\
& 6=00000110 \\
& \mathrm{P}=01010000 \\
& =00000000 \\
& \overline{\mathrm{O}}=01001111 \\
& 7=00000111 \\
& \mathrm{~J}=01001010 \\
& 9=00001001 \\
& =01011111 \\
& \overline{2} 0=00010100 \\
& \mathrm{~T}=01010100 \\
& 7=00000111 \\
& \mathrm{G}=01000111
\end{aligned}
$$

Setelah dilakukan konversi ke biner. Pada kunci 1 dan 2 setiap kuruf dilakukan perhitungan gerbang logika XOR. Pada kunci 1 untuk perhitungan XOR sebagai berikut :

$\mathrm{H}=01001100$

$\mathrm{A}=01000001$

$\mathrm{L}=01001100$

$\mathrm{O}=01001111$

Akan menghasilkan XOR $=00001010$. Pada kunci 2 untuk perhitungan XOR sebagai berikut :

$\mathrm{G}=01000111$

$\mathrm{U}=01010101$

$\mathrm{N}=01001110$

$\mathrm{M}=01001101$

$\mathrm{E}=01000101$

$\mathrm{R}=01010010$

$\mathrm{A}=01000001$

$\mathrm{P}=01010000$

$\mathrm{I}=01001001$
Akan menghasilkan XOR $=01011110$.

Setelah didapat 1 deretan biner 8 bit disetiap kunci maka kunci 1 dan kunci 2 hasil dari perhitungan XOR pada setiap kunci dilakukan perhitungan gerbang logika OR.

Kunci $1=00001010$

Kunci $2=00001010$

Akan mengahasilkan OR $=01011110$.

Selanjutnya hasil konversi dari ciphertext 1 dilakukan perhitungan XNOR terhadap hasil dari OR diatas. Didapatkan hasil nya adalah

1110100010100110111000111010011011111110

$\begin{array}{llllll}10110011 & 11100110 & 10100111 & 11111110 & 10110110\end{array}$

$\begin{array}{lllll}11101001 & 10111000 & 11101001 & 10110111 & 11111110\end{array}$

$10110101 \quad 11100100101001101110010010110011$ $\begin{array}{lllll}11110010 & 10101001 & 11101010 & 10100001 & 11100011\end{array}$ $\begin{array}{llllll}10100110 & 11110000 & 10100000 & 1111110 & 10110100\end{array}$ $\begin{array}{lllll}11100110 & 10100111 & 11110001 & 10100001 & 11101110\end{array}$ 1010011011101011101010001111111010110101 111101011010011011100110

Setelah didapat hasil XNOR dilakukan perubahan pada huruf pertama biner disetiap huruf ciphertext 1 menjadi angka 0 seperti dibawah ini.

0110100000100110011000110010011001111110 0011001101100110001001110111111000110110 0110100100111000011010010011011101111110 0011010101100100001001100110010000110011 0111001000101001011010100010000101100011 0010011001110000001000000111111000110100 0110011000100111011100010010000101101110 0010011001101011001010000111111000110101 011101010010011001100110

Selanjutnya dari perhitungan gerbang logika XNOR dilakukan konversi ke ASCII, maka akan menjadi seperti ini : h\&c\& 3f' 6i8i7 5d\&d3r)j!c\&p $\sim 4 \mathrm{f}^{\prime} \mathrm{q} ! \mathrm{n} \& \mathrm{k}(\sim 5 \mathrm{u} \& \mathrm{f}$

Dilanjutkan dengan conversi ke HEXA yang mana konversi ke HEXA adalah pada urutan ganjil saja pada hasil ASCII tadi. Maka akan seperti ini : 68\&63\&7e366'7e66986977e564\&64372)6a!63\&70

7e466'71!6e\&6b(7e575\&66. Itulah hasil akhir dari ciphertext pada kriptografi ini.

Alur enkripsi dari metode ini ada pada gambar dibawah ini : 


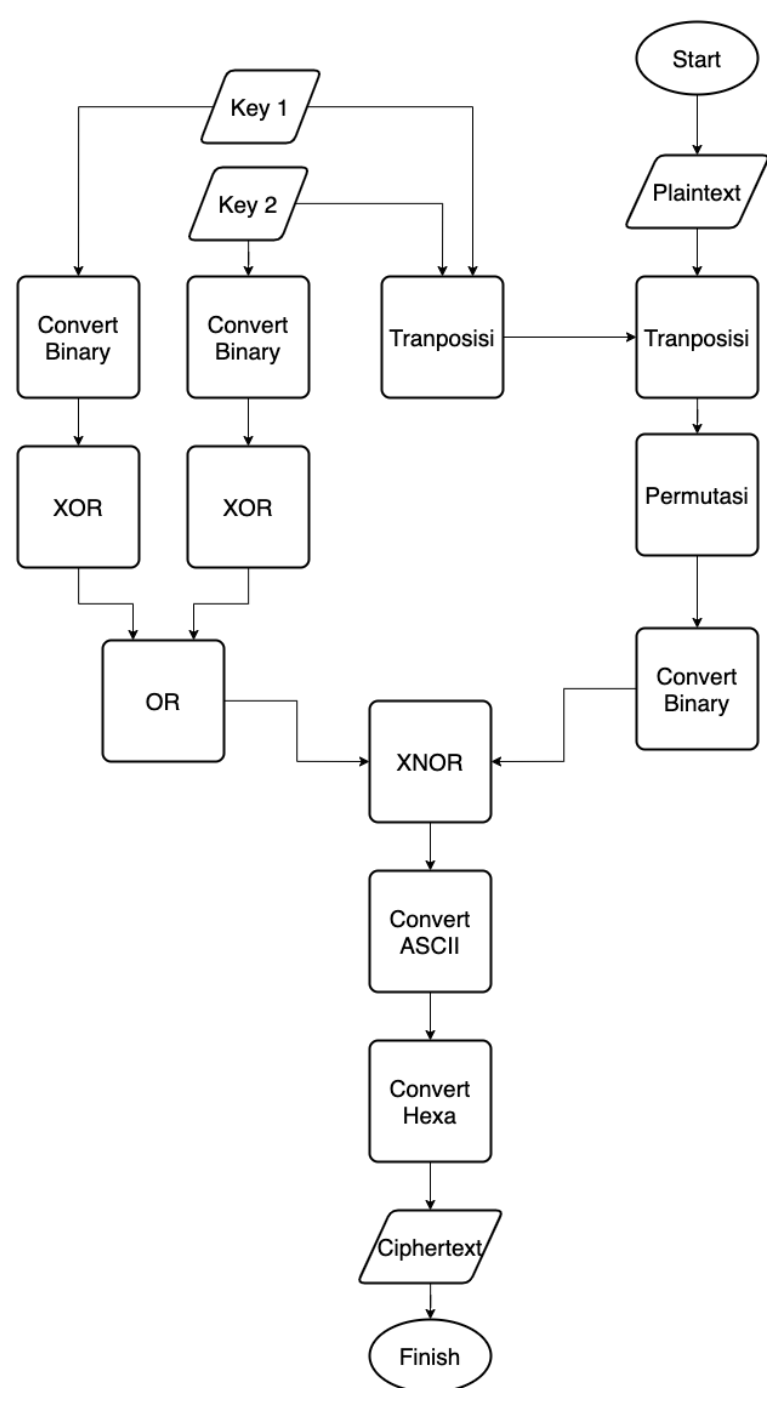

Gambar 2. Tabel Alur Enkripsi

Pada dekripsi dilakukan hal sama seperti enkripsi akan tetapi dengan alur terbalik dari enkripsi diatas tadi. Berikut gambar dari alur proses dekripsi kriptografi ini pada gambar 3 dibawah ini :

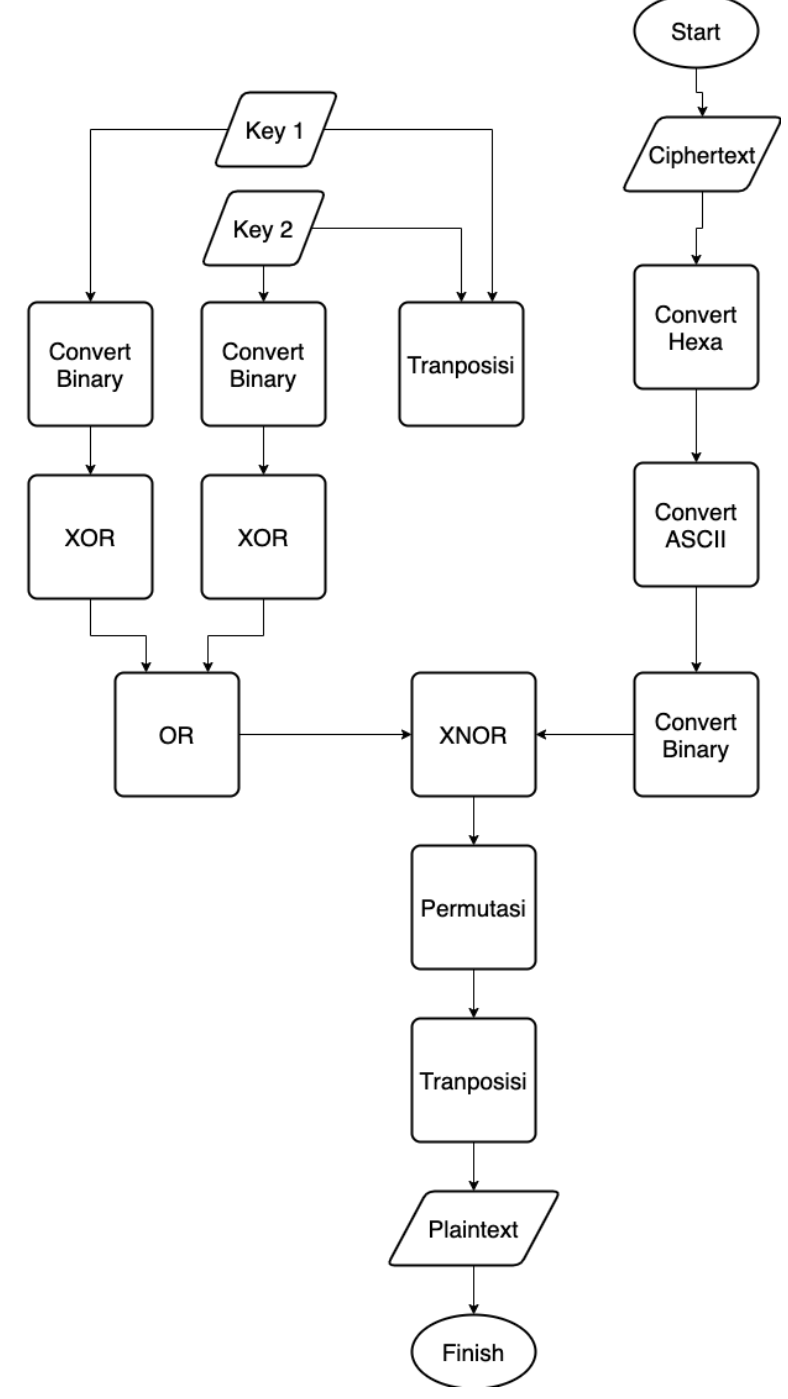

Gambar 3. Tabel Alur Dekripsi

\section{III.HASIL DAN PEMBAHASAN}

Penulis menggunakan bahasa program PHP dalam pembuatan program algoritma modifikasi Caesar Cipher. Pada program ini terdapat beberapa fungsi 3 button dan 3 input yaitu button enkripsi, button dekripsi, button proses dan pada input yaitu input plaintext untuk enkripsi dan input ciphertext untuk decript. Berikut hasil data pengujian dari implementasi pada program PHP dengan percobaan enkripsi pada plaintext SAYA MAU MAKAN KETEMPAT YANG JAUH DARI KOTA pada gambar 4 : 


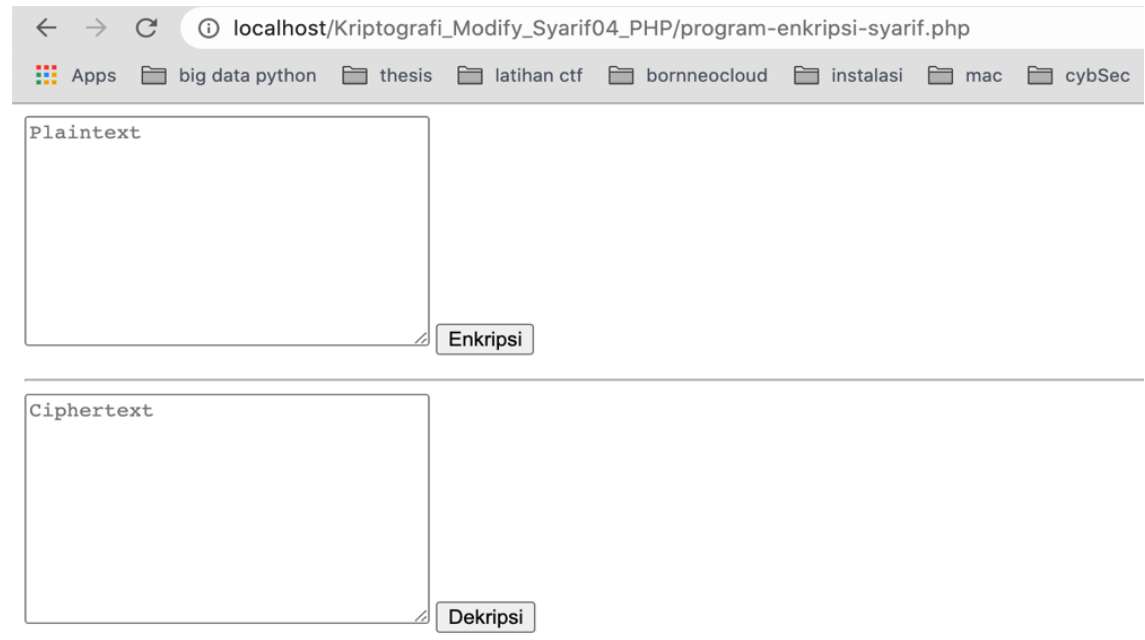

\section{Modifikasi Kriptografi BY AKHMAD SYARIF}

hanya huruf besar

SAYA MAU MAKAN KETEMPAT YANG JAUH DARI KOTA

Hasil akhir Chipertext $=6 \mathrm{~b} \& 63 \& 7 \mathrm{e} 066^{\prime} 7 \mathrm{e} 66 \mathrm{a} 86 \mathrm{a} 77 \mathrm{e} 564 \& 64072 * 6 \mathrm{a} ! 63 \& 717 \mathrm{e} 766^{\prime} 71 ! 72 \& 6 \mathrm{~d}(7 \mathrm{e} 575 \& 66$

Gambar 4. Gambar hasil aplikasi enkripsi pada kriptografi ini

Dan berikut ini juga hasil dari implementasi modifikasi algoritma Caesar Cipher pada program PHP dengan percobaan dekrip dari hasil gambar 5 :
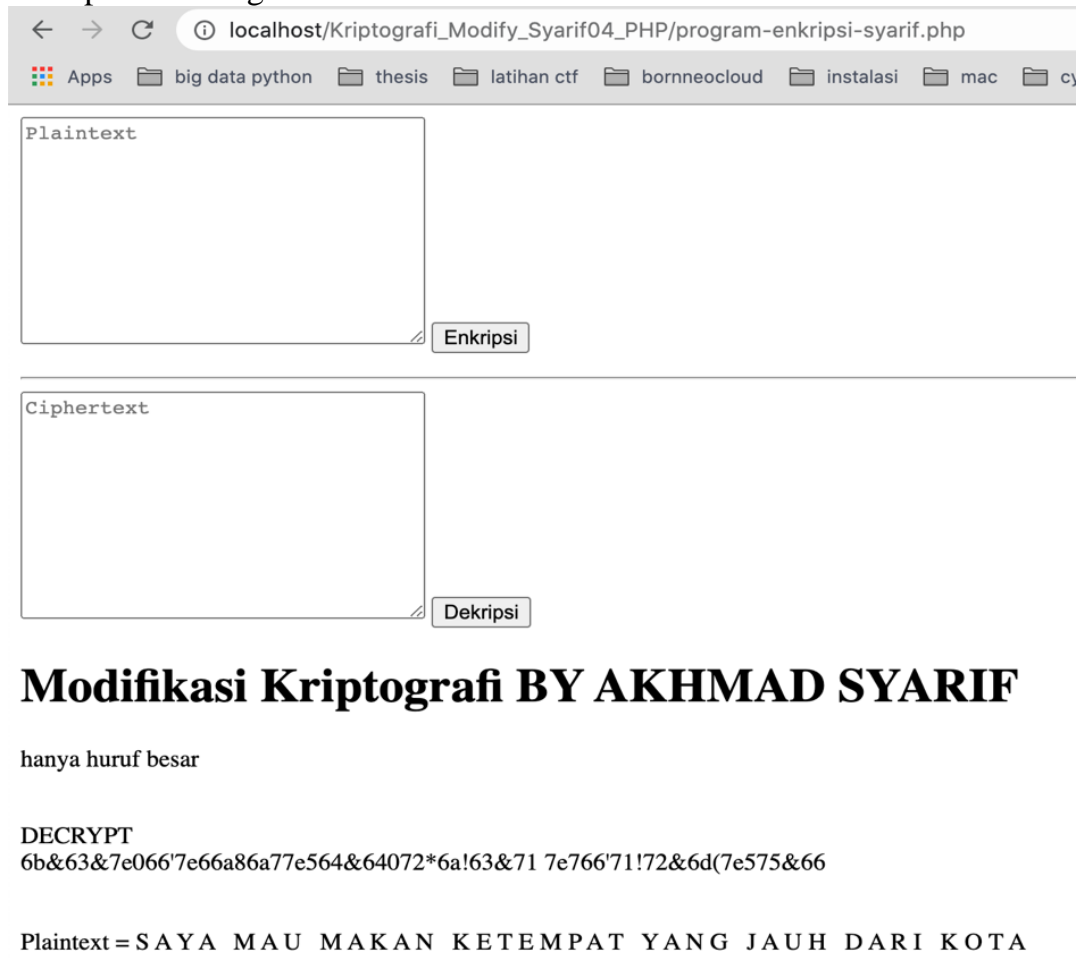

Gambar 5. Gambar hasil aplikasi dekripsi pada kriptografi ini

Kekurangan dari algoritma ini adalah tidak bisa enkripsi dari huruf kecil dan juga pada kunci yang masih static dari koding menggunakan 2 kunci.

Dari hasil program diatas dapat disimpulkan bahwa algoritma Caesar Cipher yang telah dimodifikasi menggunakan metode yang telah dibahas pada metode penelitian dengan beberapa campuran metode algoritma yang ada pada algoritma kriptografi medern dapat dilakukan dan juga dapat memperkuat kriptografi Caesar Cipher itu sendiri. 


\section{KESIMPULAN}

Dalam pengimplementasian algoritma klasik Caesar Cipher yang telah dimodifikasi dengan beberapa tambahan menggunakan tranposisi, permutasi, conversi Biner, ASCII dan Hexa dan juga perhitungan gerbang logika sebagai acuan untuk memungkinkan lebih banyak karakter dan memperkuat ekripsi ini sendiri. Dengan ini setidaknya akan menambah daftar algoritma modifikasi pada Caesar Cipher yang digunakan untuk menghindari kerahasiaan informasi diketahui selain penerima. Penggunaan 2 kunci dilakukan pada enkripsi ini. Adanya penggabungan beberapa metode mutasi, tranposisi, conversi (biner, ASCII, Hexa) yang mana membuat algoritma Chiper Caesar akan lebih kuat dan aman sehingga tidak mudah bagi hacker untuk mencoba untuk menyerang atau menemukan plaintext tersebut.

\section{DAFTAR PUSTAKA}

[1] R. Latifah, S. N. Ambo, and S. I. Kurnia, "Modifikasi Algoritma Caesar Chiper dan Rail Fence untuk Peningkatan Keamanan Teks Alfanumerik dan Karakter Khusus," Semin. Nas. Sains dan Teknol., no. 1-2 November, pp. 1-7, 2017.

[2] B. Purnama and A. H. H. Rohayani, "A New Modified Caesar Cipher Cryptography Method with LegibleCiphertext from a Message to Be Encrypted," Procedia Comput. Sci., vol. 59, pp. 195-204, 2015.

[3] G. F. Rohmi, "IMPLEMENTASI ALGORITMA CHIPER CAESAR UNTUK ENKRIPSI DAN DEKRIPSI PADA TABEL ASCII MENGGUNKAN BAHASA JAVA," ResearchGate, 2016.

[4] F. I. Lubis, H. F. S. Simbolon, T. P. Batubara, and R. W. Sembiring, "Combination of caesar cipher modification with transposition cipher," Adv. Sci. Technol. Eng. Syst., vol. 2, no. 5, pp. 22-25, 2017.

[5] P. Verma, G. Singh Gaba, and H. Monga, "Modified Caesar Cipher Using Rectangular Method for Enhanced Security," J. Commun. Technol. Electron. Comput. Sci., vol. 8, 2016.

[6] R. Munir, Kriptografi Edisi Kedua. Bandung: Informatika, 2019.

[7] I. Gunawan, "Kombinasi Algoritma Caesar Cipher dan Algoritma RSA untuk pengamanan File Dokumen dan Pesan Teks," InfoTekJar (Jurnal Nas. Inform. dan Teknol. Jaringan), vol. 2, no. 2, pp. 124-129, 2018.

[8] R. P. Islami, "Modifikasi Algoritma Caesar Cipher Menjadi SPICA-XB ( Spinning Caesar dengan XOR Binary )," J. Mantik, vol. 3.

[9] N. S. B. Sembiring, "Perancangan Aplikasi Kriptografi dengan Metode Modifikasi Caesar Cipher yang Diperkuat dengan Vernam Cipher untuk Keamanan Teks," e-jurnal JUSITI, vol. 5, 2016. 